\title{
Research on the Application of Positive Psychology in the College English Teaching
}

\author{
Huayan Sun \\ Humanities and International Education College, Xi'an Peihua University, Xi'an, China \\ 315112580@qq.com
}

\begin{abstract}
The purpose of the English teaching is to develop the students' English comprehension and language proficiency, and to help the students prepare for a better adaptation to the future career. Currently, the whole society pays close attention to the psychological problems of college students. The college should also pay attention to it. It is related to the teaching effect and the healthy development of the students. Therefore, we must attach great importance to the teaching process. In view of this, this paper explores the ways to improve college English teaching from the perspective of positive psychology, and creates a good environment for the improvement of college English teaching quality and the overall development of students. The research has profound significance.
\end{abstract}

Keywords: college English, positive psychology, English teaching.

\section{Introduction}

Positive psychology is a breakthrough in modern psychology. It uses scientific principles and methods to study people's happiness experience, advocates the positive orientation of psychology, pays attention to people's positive psychological quality, and pays attention to people's health and happiness and harmonious development. In the practice of modern college English teaching, the application value of positive psychology has gradually received attention. In the process of college English teaching, through the guidance of students' positive psychology, it has formed a self-management and self-education mechanism. In the process of college English teaching, the application of positive psychology has important practical value. Therefore, by analyzing the current college English teaching and the current situation of students, we explore how to achieve the penetration and application of positive psychology.

\section{The Current Situation of College English Teaching}

With the rapid development of society and the integration of globalization, the future professional development requires for a quite high English ability, such as presentation of research results, academic exchanges, business meetings, cross-border communication, etc., but the current practice of college English teaching can't match the need. For example, from the perspective of teachers, there is a burnout mentality in career planning and lack of initiative in curriculum construction. During the whole process, the teachers pay little attention to the connection between the teachers and the students.

In the teaching process, the students' positive psychology can not be fully mobilized, because the teacher's teaching arrangement lacks active exploration space, and the students face many difficulties in their study, many students' psychological frustration leads to their lack of learning motivation and affects the active participation enthusiasm. Second, the content of the teaching evaluation is rigid and the form is single. It is difficult to mobilize the students' enthusiasm on the English study, and the teaching evaluation also loses its influence on the development of students. In response to these shortcomings, college English teachers can plan and apply English teaching courses from the perspective of positive psychology. 


\section{Psychological Analysis of Students in College English Teaching}

\subsection{Lack of Perseverance}

English learning sometimes makes people feel boring, as it a process of learning a language. To learn it well, we need to spend a lot of time and energy practicing pronunciation, memorizing the grammar rules. This process seems really troublesome. There is no shortcut to the learning of the language. Due to the lack of the competition awareness, the students' English learning motivation reduces. Some students will give up when they encounter a little difficulty, so they can't learn English well.

\subsection{Fear of Making Mistakes}

Domestic English teaching focuses on exams. Most students study English to pass the exam and obtain an English certificate. So they pay all the attention on how to solve the exercises, not the use of the language itself. Until the university stage, some students begin to pay attention to spoken English. In the university, there are various English speech contests to make up the shortcoming of the "dumb English" education the students accepted before. However, many students are afraid of making mistakes and are not confident enough about their English pronunciation, so they dare to express themselves in English. They will adopt a far-sighted attitude towards various forms of English activities and will not dare to participate and experience themselves, it's easy to form a vicious circle. They will have no motivation to learn English.

\subsection{The Learning Method is not Scientific}

Many college students didn't use the scientific learning methods in the process of learning English. They use the common method when learning English in the class: rote memorizing and constantly doing various exercises to consolidate the knowledge. They do what the teacher asked them to do, but they never think about the methods themselves. But after a while, many students began to retreat. [1] Because language learning without practical application can not attract the students to persist for a long time, the charm of English lies in the application. To learn a language well, it is necessary to continuously improve and learn in practical applications. But the students don't know the charm of English linguistics. Of course, they don't use the Internet to collect more interesting English knowledge and maintain their sense of language and interest.

\subsection{English Learning is too Utilitarian}

Most students aim to get English qualifications to increase their chances of success in the job hunting. However, many college students do not positively transform this concept of "study and promote learning". They always learn English fluently and study nervously for a period of time to achieve their objective. However when they got it, they slacked off. This kind of English learning is short-term, and the knowledge they got by centralized learning is easy to forget, and in fact, students don't really take English learning as part of their own lives, so the results are not satisfactory.

\section{College English Teaching Construction Strategy from the Perspective of Positive Psychology}

\subsection{Constructing College English Teaching from the Perspective of Teachers}

As the leader of teaching, teachers' psychological environment has a direct impact on the construction of English audio-visual courses. Positive psychology emphasizes subjective well-being. Therefore, in the teaching process, the university should comprehensively plan the professional development of the English teachers. From the perspective of teachers' professional ability, the training of the teachers' English listening and speaking ability should be strengthened. The professional ability of English teachers in many vocational colleges can only adapt to English basic courses and comprehensive courses. They don't use flexible methods to teach. As a result, they lack 
support in their career development. In response to this, universities should strengthen the professional training of English teachers, and develop scientific career planning for them, improve the teachers' recognition of their professional development, and thus enhance the enthusiasm of participating in the construction of English courses. In addition, English teachers also need to lead by example, actively improve the consciousness of constructing a positive psychological environment, adjust the curriculum, provide appropriate learning-related materials for students according to the specific circumstances of students, and actively adjust teaching methods to guide students in a positive attitude.

\subsection{Constructing College English Teaching from the Perspective of the Students}

From the perspective of positive psychology, the construction of the university English curriculum should be based on the growth and the development of the students. They should pay more attention to the formation of students' positive emotional quality, the generation of teaching environment conducive to positive emotional experience and the students' autonomy and initiative.[3] The English teachers should do self-education, self-management and self-development. Based on this, English teachers must first establish a perfect teaching and training goal, and use the emotional attitude for the long-term development of students. Infiltrate the humanistic spirit in the teaching curriculum, tap the humanistic value, and promote students to establish positive and healthy values. Second, they need to focus on the students. The construction of internal driving ability integrates students' subjective initiative into the teaching practice, combines students' psychology, emotions and thoughts to construct college English teaching process; they should finally pay attention to students' selfeducation and guide the students in the language teaching. To achieve the reflection, and to formulate learning programs in combination with teaching objectives, the English teachers should improve comprehensive literacy in self-supervising and self-management.

\subsection{Constructing College English Teaching from the Perspective of Teaching Evaluation}

Teaching evaluation is not only a test of the learning effect of the students, but also an urging and motivation for the learning process of the students. Therefore, it is an important method to construct a positive psychological environment. English teachers should carry out the teaching evaluation from the following two points: First, enrich the form of assessment from the positive psychological and emotional development of the students, explore diversified assessment methods, and develop vocational education in the process of university English teaching and the teaching results. Combined with the comprehensive quality training, students' English comprehensive literacy is tested from the aspects of the students' English reading, listening and expression, which lays a foundation for their career development. Second, they should pay attention to the incentive function of assessment. In the process of students' English learning, teachers should summarize the learning experience and the learning problems that students have obtained according to the assessment results, and adjust the teaching evaluation content and evaluation method according to the comprehensive development requirements of students. To enable the students to see their strengths and weaknesses, and to encourage them to focus on their own development, the English teachers should constantly help the students improve their abilities to learn independently and achieve comprehensive quality development.

\section{The Significance of Positive Psychology in College English Teaching}

\subsection{Conducive to Create a Good English Learning Atmosphere}

The good learning atmosphere in the university campus will profoundly affect every student in it. Teachers understand the psychology of their students and can propose more targeted solutions, such as holding lectures to guide students on how to learn English scientifically. Hold a book sharing session to learn to share excellent English reading materials. Through the holding of various activities, the teachers' careful guidance, teachers and students have joined hands to set off a wave of learning English. 


\subsection{Conducive to the Establishment of a Harmonious and Harmonious Teacher-student Relationship}

A good teacher-student relationship is a catalyst for students' learning outcomes. English teachers understand the psychology of college students and master the secrets of getting along well with students. For example, if the English teachers understand the reasons why students are unwilling to answer the questions, they will not always be distressed by the poor interaction of the classroom, and they can find better solutions. Teachers can encourage students to share interesting English phenomena in their lives. Each class they encourage the students to answer questions in English and give them timely recognition. They affirm the advantages of each student and make them easy to learn English in class. After all, many students like to be recognized. English learning starts with a good English teacher.

\subsection{Help to Enhance the Students' Self-confidence}

Saying goodbye to "dumb English", allow the college students to participate in the English class actively, which not only requires the unilateral efforts of teachers, but more importantly, to improve students' self-confidence in English learning. In order to fundamentally solve the problem, the teachers should understand that students do not like the reasons and psychological characteristics of speaking English, they will actively encourage the students to speak English. For students whose pronunciation really needs to be improved, teachers should encourage the students to make persistent efforts based on the flash points of the students.[5] When students have self-confidence, they will learn English more actively. The more they learn, the more skilled they are, and then they will want to express themselves. This kind of virtuous circle benefits students a lot.

\subsection{Conducive to the Long-term Development of Students}

Nowadays, economic globalization and political integration are accelerating. It is very important to learn English well for the college students who want to find an ideal job after graduation. If the students can't learn English well in the university, they will face very fierce competition in the society. They will feel high pressure, and even hinder the development of their talents. English teachers should understand the students' learning psychology, and then they can find the crux of the problem with the right medicine, so that they can solve the students' English learning problems smoothly and help them develop the concepts and interests of daily learning English, which will make them more competitive in the future.

\section{Conclusion}

All in all, the use of positive psychology in the college English teaching is beneficial to improve the teaching effect. It helps them create a good atmosphere of English learning and establish a harmonious relationship between teachers and students, enhance the students' self-confidence, and promote self-development of college students.

The students can learn a lot of practical methods during this process. They will actively know the pragmatic function of the language. From the psychological aspect, the students can get the inner motivation to promote their own English learning

\section{References}

[1]. Zhang Ye, Zhou Dajun. Research on classroom participation model of college English students [J]. Foreign Languages, 2004, (6): 28-33.

[2]. Wen Qiufang, Sun Min. Comment on the problems existing in the cultivation of speculative power in foreign language teaching in colleges and universities [J]. Foreign Language Teaching Theory and Practice, 2015, (3): 6-12. 
[3]. Luo Yutao. Training Strategies of Students' Psychological Quality in English Interpretation Teaching[J]. Educational Theory \& Practice, 2018, VOL.38 No.30 P53-P54.

[4]. Liu Xue. How to Implement Effective Peer Cooperative Learning Strategies in Middle School English Teaching[J]. Teaching and Management, 2014.

[5]. Xu Ling, Wen Yaofeng. Research on Cooperative Learning Model in English Teaching[J]. Teaching and Management, 2011.

[6]. Kong Xiangguo, Ding Yang. Psychological Intervention of College Students' English Learning Behavior Decision[J]. Journal of Changchun Teachers College, 2012, 31(1): 172-174. 